\title{
Forest Entomology or Entomology in the Forest? Canadian Research and Development
}

by

\author{
D.R. Wallace ${ }^{1}$
}

\begin{abstract}
Antecedents
From its beginnings, the science of forest entomology has been closely tied to man's view of the forest, either as a source of materials to enhance his life, the forest as part of his inner being, or the forest as an essential part of preserving the earth as he knows it. Only as fears that there might be shortages of timber arose and intensified, usually coupled with great pestilences on the trees, was much attention paid to the insects that live in the forests. For western man this began in the seventeenth century in central Europe and became pronounced by the nineteenth century (Schwerdtfeger 1973). The early students of forest insects were not professional entomologists. They were naturalists. The first great forest entomologist was the Berliner J.T.C. Ratzeburg, who collected all the early naturalists' works on forest insects, corresponded with observers throughout western Europe, travelled extensively to make personal observations, and studied insects kept in cages outdoors. From his analysis of the data collected in this systematic approach, he produced the three-volume treatise known as "Die ForstInsecten" between 1837 and 1844. The foundation of the "inventory phase" of forest entomology was firmly laid and to-day it is still inspiring and humbling to examine these $150+$ year-old books with their magnificent plates.
\end{abstract}

In the United States a comparable stage of development was reached with the publication of "Insects injurious to forest and shade trees" by A.S. Packard in 1890, supplemented by E.P. Felt's illustrated book "Insects affecting park and woodland trees" which appeared in 1905 (Graham 1939). The emphasis on shade and park trees (and woodland seemingly differentiated from large tracts of forest) is indicative that there was little feeling of a threat of timber shortages. For this reason entomological work was concentrated on orchard and crop plants. The other emphasis in the work is that it deals mainly with problems in the eastern United States.

Shifting from the United States to Canada, a further telescoping of time occurs through the naturalist and inventory stages of development of entomology. The general topic of this progression in science in Canada, although not for entomology, is clearly defined in Suzanne Zeller's book "Inventing Canada, Early Victorian science and the idea of a transcontinental nation"' (1987). The forest, which she has described as "the unrelenting tangle of primordial forest" as seen by

Forestry Canada. Great Lakes Forestry Centre, P.O. Box 490, Sault Ste. Marie, Ontario P6A 5 M7. our forbears was to them initially an enemy to be conquered in their settlement of a new land. The forests were a threat, not something threatened by pests such as insects. The settlers were harassed by biting insects and their crops and orchards were attacked by pests. They saw and recorded sporadic plagues of insects affecting the forests as events to wonder at. In any case they were helpless to deal with widespread outbreaks. Interest in insects of the forests was totally contained within agricultural entomology, a factor that has played a vital role into the recent history of forest studies. A second major influence from early times has been the close relationship with the United States.

In 1862 there were known to C.J.S. Bethune, a theologian, headmaster, and later professional entomologist, only 36 persons in Canada "interested in collecting and studying insects" (Glen 1956). William Saunders, a chemist/druggist and collaborator with Bethune, published a book on orchard pests in 1883 and became the Director of the Experimental Farms Branch of The Dominion Department of Agriculture in 1886. Another amateur naturalist, James Fletcher, an accountant in the Library of Parliament, was at first Honorary Entomologist (1883), then Dominion Entomologist (1884) while still in the Library of Parliament, and finally professionally as the Dominion Entomologist and Botanist in 1887. He died in the position in 1908. The following year the era of the amateur naturalists and a significant part of the inventory period came to an end with the appointment of C.G. Hewitt, a Doctor of Science in zoology and entomology, as Dominion Entomologist. G.J. Spencer (1964) remarked on the arrival of the new type of entomology and the initial unfavourable impression created by Hewitt. However, the blossoming of entomology in Canada was underway, with rapid developments in exploring the Canadian insect fauna and applying the experimental approach to studying pests (the period of causality research, Schwerdtfeger 1973).

Hewitt became aware of several forest insect outbreaks very soon after becoming Dominion Entomologist in 1909. $\mathrm{He}$ turned his attention to these problems and when he organized the Entomology Branch of the Agriculture Department in 1914, he established the Division of Forest Insects. J.M. Swaine, a Nova Scotian who had trained at Cornell University and lectured at Macdonald College of McGill University before joining the federal service in 1912 , became the first Chief of the Division and the first Canadian to "devote his time continuously to forest entomology" (Prebble 1956). 
So emerged forest entomology in Canada as a named, organizational entity, some 76 years ago, an interval shorter than the first 100 years of the International Union of Forest Research Organizations, which will be addressing research needs in forestry for the next century at its Congress this August in Montreal. Many of the details of the history that are touched upon in the foregoing paragraphs and other insights into the people and events that have shaped entomology in Canada can be found in several papers and books (Glen 1956, Spencer 1964, Anstey 1986, Cody et al. 1986, Richmond 1986, Swaine 1928, de Gryse 1947). This article will not review the minutae of changes in structure and operation of government and educational departments and of industries as they have interacted in forest entomological research. Rather I hope to provide a foundation for looking at the broad contributions by Canadian forest entomologists and then to make some comments on the future for our research.

\section{Men and Influences}

To link the story to current times, something should be said about some individuals who were responsible for creating the environment that allowed rapid and significant progress in forest entomology. A national peculiarity is that Canadians who contribute to culture, science, and social well-being often receive less notice in Canada than outside our own country. Many of our forest entomologists have been native Canadians; others have come from various parts of the world, but there is no distinction in the commitment that they have applied to their work, and it is unfortunate that space allows so few to be recognized in this article.

C. Gordon Hewitt, who became Dominion Entomologist in 1909, had worked on the larch sawfly, Pristiphora erichsonii $(\mathrm{Htg}$.), in the Lake District of England before his appointment in Canada, and he was therefore receptive to investigating forest insect problems here (Hewitt 1910). Coincidentally, a major outbreak of the sawfly was taking place in eastern North America at the time of his arrival and he continued his scientific work, producing a comprehensive bulletin on the pest (Hewitt 1912), and began the first organized biological control program in Canada (Beirne 1973). The original releases of the parasite Mesoleius tenthredinis Morley were made between 1910 and 1913 with material from England. Hewitt so established professional forest entomology in Canada, elevated it to an identifiable entity, and began the development of biological control. Biological control work was also spurred on at that time by a severe outbreak of the brown-tailed moth, Nygmia phaeorrhoea (Donov.), and the anticipation of invasion by the gypsy moth, Lymantria dispar (L.), from the United States. Further, it was Hewitt that brought about the passage of the Destructive Insect and Pest Act in 1910 in recognition of the fact that many of the insect problems in Canada were from introduced species.

Hewitt passed the direct responsibility for developing forest entomology to J.M. Swaine in 1914, a responsibility which Swaine exercised until 1934 when he became Director of Research for the Dominion Department of Agriculture. Swaine's personal research made major contributions to the biology and taxonomy of the Scolytidae and Cerambycidae. He was also involved in spruce budworm damage surveys in Quebec and Ontario, surveys that saw the first use of aircraft to cover the vast area. He took part in the first trials of aerial application of insecticides. In British Columbia, Swaine carried out appraisals of bark beetle outbreaks. Under J.M. Swaine's leadership the first expansion of scientific forest entomology in Canada took place. There were extensive studies on many insects besides the spruce budworm and bark beetles (Swaine 1933), carried out by about 15 entomologists and a similar number of assistants (Prebble 1956). At first, most of the work was run out of Ottawa. Under Swaine, regional laboratories were established in Vernon, B.C. (1919), Indian Head, Sask. (1923), and Fredericton, N.B. (1923). Investigations in Quebec, Ontario, and the forest areas of Manitoba were dealt with from Ottawa. During the period, surveys were expanded and field ecological studies became more complex. The use of aircraft grew.

The growth and development of the Swaine period were followed by even greater activity and achievements under the influence of J.J. de Gryse and the onset of a severe outbreak of an introduced insect in eastern Canada. Mr. de Gryse, born and educated in Belgium, came to Canada from the United States in 1923 with an appointment as entomologist at Indian Head. He undertook intensive ecological studies of a number of defoliators in different parts of Canada, but he is not remembered especially for his own original scientific contributions. In 1934 de Gryse took over from Swaine as Director of the Division of Forest Insects, the position he held until his retirement in 1952. Mr. de Gryse applied his exceptional vision, dedication, and organizational skills to mold forest insect research into the basic structure underlying the present day federal insect work and to establish the physical distribution for most of the federal regional forestry centres. His knowledge and imagination fostered much of the Canadian forest entomological research and practice recognized internationally.

In 1930 an outbreak of an introduced sawfly, later determined to be the European species Gilpinia hercyniae (Htg.), was discovered on the Gaspé Peninsula of Quebec. This outbreak developed to become a very serious threat to the spruce forests of eastern North America. Its discovery underscored the need for a formalized detection service to assure that forest insect infestations either of native pests or of introduced species would not go undetected until they had become extensive and a major problem. Hewitt and Swaine had both forseen the need for this service, but it was de Gryse who founded the Canadian Forest Insect Survey in 1936. At first the Survey was operated wholly from Ottawa and was carried out by many co-operating agencies. It had strong support from provincial forestry ministries, forest limit-holders, and industry. The Canadian Society of Forest Engineers and the Canadian Pulp and Paper Association were also instrumental in its establishment. Later the Survey functions were taken over for the most part by a federal government staff operating out of the regional research laboratories. The growth and diversification of the Survey as a national organization has been described by McGugan (1958). The Forest Insect Survey became much more than a simple detection service. Its work included a great deal of biological investigation of many species in the forest and also traced the rise and fall of populations, providing a core of information that supported and promoted much of the intensive research on major pests. Even though the Survey may be regarded as an inventory approach, it was organized on a much broader concept than merely cataloging collections.

The European spruce sawfly outbreak, in addition to lending urgency to the establishment of the Forest Insect Survey, also brought about notable advances in a number of scientific areas. The research on the sawfly was multidisciplinary: biosystematics to determine its identity and basic characteristics; quantitative sampling methodology and 
damage appraisal; physiology in relation to epidemiology; and control, especially biological control. This represented a major thrust into the kinds of research that are practiced today. M.L. Prebble was a principal participant in the program throughout the 1930s and his contribution to forest entomology in Canada will be discussed later. The effort to control the European spruce sawfly was successful and represents a prime example of classical biological control of a forest pest (Reeks 1953, Bird and Elgee 1957). By the early 1940s the outbreak had subsided and there has not been a reoccurrence, although the distribution range of the pest continued to expand. Of special note is the role that a nuclear polyhedrosis virus played in the control and the influence that this has had on forest entomology in Canada.

In the 1940's de Gryse continued the development of research and facilities with new laboratories in Victoria, Sault Ste. Marie, and Calgary to strengthen the regional capabilities. The Sault Ste. Marie laboratory, a joint venture with the Ontario Department of Lands and Forests, was designated to be the main centre of the Division of Forest Insects for fundamental studies in ecology, biometeorology, behaviour, insect pathology, and cytology and genetics. It was completed in 1945. Although the research at the different laboratories dealt with many pests, depending on the problems and priorities of the region, the spruce budworm became the pervasive influence on programs across eastern Canada. The Green River Project was initiated in New Brunswick in 1944 to investigate the population dynamics of the spruce budworm through intensive field and laboratory entomological research combined with forest management studies. As with the formation of the Forest Insect Survey, the Canadian Pulp and Paper Association played an important part in setting up the Green River Project. The New Brunswick Department of Lands and Mines, the forest industries, and the federal Division all took their respective functions in this work to develop forest management practices in the broadest sense to deal with the spruce budworm. From the onset of the fundamental work in Sault Ste. Marie and the population dynamics project in New Brunswick, spruce budworm research has been the dominating component of forest entomology in the eastern Canadian establishments to the present.

As well as proposing one initial, principal centre for fundamental research, de Gryse later organized sections for specialized work in insect pathology, cytology and genetics, bioclimatology, and chemical control, each comprised of working associations of scientists dealing with related disciplinary problems. This arrangement promoted cross fertilization of ideas and allowed the science to progress with freedom from administrative and regional responsibilities. Fundamental research became disseminated from the Sault Ste. Marie laboratories and sections throughout the whole federal organization.

When de Gryse retired in 1952 as chief of the new Forest Biology Division (forest entomology and forest pathology), he was succeeded by M.L. Prebble. Prebble had been the head of the Victoria laboratory during its formative years 1940-1945 and then the new Forest Insect Laboratory in Sault Ste. Marie from 1945 until 1952 during its period of most intensive development. Prebble's career as a scientist and senior research director are outlined in an accompanying biographical sketch. In Ottawa, Prebble continued the development of federal entomology research along lines similar to those already determined. He served as a senior science manager, for several years as an Assistant Deputy Minister, until he retired in 1974 . This period was marked by the integration of forest entomology and pathology with other aspects of forestry.

In addition to Hewitt, Swaine, de Gryse and Prebble, there was another man who contributed to the creation of a research climate that brought about the flourishing of agricultural research, including all aspects of entomology. This was K.W. Neatby, a plant breeder, who became Director of the Science Service of the Department of Agriculture in 1946 (Anstey 1986, Cody et al. 1986). Until his death in 1958, he encouraged his researchers by direct contact and administrative action. The growth and progress of systematic entomology during this time was an essential complement to the surveys and many other research activities of the forest entomologists.

Finally, one must recognize the role of universities in forest entomology in Canada. Part of the vitality of the research programs has stemmed from the diversity of backgrounds that the scientists brought with them and further developed during their careers. Many forestry graduates became entomologists, especially during the period of rapid growth from 1945 to 1955. Others came from zoology, botany, chemistry, meteorology, and agricultural entomology. The research done by university scientists and their graduate students made an important contribution to Canadian achievements in forest entomology.

\section{Achievements}

The preceding section on "Men and Influences" sets the scene for Canadian contributions and successes in forest entomology. A brief statement of accomplishments now follows, giving, where possible, a broader assessment as seen by others outside the Canadian community.

\section{Survey}

The Canadian Forest Insect and Disease Survey (FIDS) has developed as a major national pest surveillance organization, recognized internationally and studied by authorities in other countries desiring to establish a similar service. In addition to monitoring pest abundance, it has added to the knowledge of the insect fauna across the broad range of forest types in Canada, and serves to detect potential new pests that may have entered Canada.

\section{Taxonomy}

The broad knowledge base on the identity of forest insects and their biology, brought together by the FIDS and many research studies, has contributed to the biosystematics of many insect groups. Systematic methodology was advanced by the cytotaxonomic work of S.G. Smith and his associates, which, for example, contributed to definition of species in the weevil genus Pissodes. Other research has added to the understanding of speciation, variation, and distribution in the Choristoneura moths, which include the spruce and jack pine budworms, the western spruce budworm, and several other species feeding on conifers. The identification of the immature stages of representatives of many other groups and descriptions of their life history and habits have utilitarian value. For example, knowledge of the bark beetles and woodborers has made possible more effective salvage of both fire- and insect-killed timber.

\section{Biological Control}

Research on natural enemies and its application in biocontrol has been thoroughly reviewed by McGugan and Coppel (1962), Corbet and Prentice (1971), and Kelleher and 
Hulme (1984). More recently, Hulme (1988) evaluated the Canadian record in applied biological control. In one-third of 21 cases examined, the pests have been almost permanently controlled, and partial control was achieved in another onethird. In the remaining cases, it was either too early to make an evaluation or efforts were unsuccessful. Just under half of the examples involved insect parasitoids or predators, the remainder entomopathogens. All of the work with parasitoids until the last decade has used the classical or inoculative approach. Recently some successful experiments in the use of inundative control with the egg parasitoid Trichogramma have been carried out (Smith and Carrow, in press).

The investigation of insect pathogens for insect control has been highly developed in Canada, principally at the Insect Pathology Laboratory which became a national institute and now is functionally part of the Forest Pest Management Institute in Sault Ste. Marie. Angus (1964) has outlined the history of work and contributions to that time. Steinhaus, the emminent American insect pathologist who died in 1969, recognized the importance of the Canadian research in an international perspective. It was de Gryse's plan to have all aspects of insect pathology from the most fundamental to the applied covered by the work in Canada. This goal has been achieved to a major extent. Such problems as the chemical structure and replication of insect viruses, the taxonomy of entomopathogenic fungi, and the mode of action of Bacillus thuringiensis have been investigated. Participation in the development of the use of $B$. thuringiensis as an effective operational control for forest lepidoptera like the spruce budworm and the continued improvement of B.t., are principal achievements of this research.

\section{Insect Ecology}

Insect ecology in the broadest sense has been advanced significantly by the work of W.G. Wellington, whose career, contributions, and honours have been described by Henson and Stark (1988). They list 112 scientific publications singly and jointly authored that cover a vast range of insect science. The contributions of his many associates and students must also be added to Wellington's work to assess the total impact of this area of Canadian forest entomology.

Going beyond all the component parts of forest entomology is the need to describe and understand the dynamics of the pest populations in order to be able to forsee problems and to determine the most suitable course of action to deal with the pest. The spruce budworm population dynamics studies based on the Green River Project led by R.F. Morris and the almost 50 years of continuing research form one of the principal case histories in insect population analysis. In part, the need to more fully understand the long-term implications of the budworm population dynamics and to try to use this information to devise strategies to live with the budworm, contributed to the development of systems analysis and modeling as tools for resource management. The work of C.S. Holling and his colleagues is recognized internationally in this field.

The accomplishments that have been outlined have dealt mostly with research and not with the management problems of protecting the forest from unacceptable damage. The operational aspects of forest insect control in Canada are the responsibility of the provincial authorities and in some regions large scale control programs have been taken against several pests, especially the spruce budworm in eastern Canada. The comprehensive work "Aerial Control of Forest Insects in Canada" edited by M.L. Prebble and published in 1975 provides an assessment of the major operations to that date. Waters and Stark (1980) discuss the Canadian work in a broader context.

\section{Needs and Directions for New Research}

There seems to a logical progression of research for the future, leading from the accomplishments to date and taking into account both the changing physical environment and the social and economic needs of the country.

1. A strong national survey of forest pests to continue the surveillence for new outbreaks of known pests and to document the progression of existing outbreaks will remain essential. Methodology in sampling and quantitative measurement of population change need to be addressed, taking into account all modern technology and research results. Analysis of insect distribution and abundance data on hand should attempt to determine indicator species that can be monitored to detect responses to the forecast climate change. Definite responses by insects may be detected well in advance of responses in the more slowly changing forest. For the same reason it may be necessary to extend the surveys beyond the usual northern limits and to pay special attention to the emergence of new pest species, both native and migrant from other regions. Recent attention to the quantitative assessment of pest impact on the forest needs to be continued and intensified as a part of more rigorous forest management.

2. Existing population and biological information needs to be organized, analyzed and integrated into suitable tools for forest managers to maximize the return on research investment to date and to assure that the best possible protection options are incorporated into generalized forest management systems. An example of this approach is described by Coulson et al. (1989), using the southern pine beetle as a case study.

3. Fundamental research on population dynamics of major pests should be continued and enhanced to try to understand and anticipate population change, and to provide a framework for research on better pest management techniques within a general forest management system. This implies a wide range of intensive studies on both the pest and the host tree.

4. The investigation of improved management techniques, especially the use of biological agents, must be increased in the anticipation that conventional chemical applications will be largely eliminated. The long forest crop rotation times, the relatively low unit area value of the crop, and the large areas that may require treatment, suggest the urgency for low-cost methods. The use of inoculative releases of parasitoids is one technique that has not been given concentrated attention for native pests and may have a good benefit:cost ratio. Inundative releases and management to enhance naturally occurring parasitoids and predators should be investigated for use in special circumstances where the crop to be protected is very valuable and restricted in extent, such as seed orchards. The continued development of microbial control agents to widen the range of pests that can be treated, to improve the effectiveness and to lower the cost is vital. There is the potential for using molecular biological alteration of biological agents to achieve these goals. 


\section{Future in Question}

In a recent article entitled "Entomologists Wane as Insects Wax", Constance Holden (1989) has pictured the discipline as one in decline. She bases this conclusion on interviews with several prominent American entomologists at the 100th anniversary meeting of the Entomological Society in 1988. In recent years there has been a loss of discipline identity along with declining numbers of entomologists and research funding, especially for fundamental organismal and evolutionary work. This has occurred despite increasing pressure to deal with problems in food supply and disease control in manners that do not contribute to ecosystem destruction and species extinction. Forest entomology in Canada is a clear example of this trend. Eidt (1989) shows the drop in federal scientists doing spruce budworm research as more than a halving and suggests that the numbers of university and contract researchers follow the same pattern because they rely largely on federal money. Non-budworm research has declined to an even greater extent from the lack of support for work on the systematics, biology and general ecology of many forest insects that are not judged to be of immediate importance.

Two snapshots of forest entomology tell the same story. At the 10th International Congress of Entomology held in Montreal in 1956, between 50 and 60 Canadian forest entomologists in attendance made major contributions in many program areas. In addition there were participants from the related areas of biological control and systematics with significant forestry connections. Thirty-two years later in 1988 , the 18th International Congress was held in Vancouver and fewer than 30 Canadian forest entomologists took part. Forest entomology was a much more modest part of the program than in 1956. There were simply many fewer forest entomologists to attend and less support for them to participate in international science.

Other science disciplines in forest research seem to be facing the same problem. The emphasis has turned so far in favor of short-term, applied work that there is a danger of stagnation at the current level of knowledge, much of which dates back quite a few years. The present efforts to integrate information into models that mimic nature and support sound management decisions rest on the accumulated data. The great strengths of the recent trends in process modeling and the development of knowledge-based decision support systems are their capability to organize, integrate, and provide tools to aid the interpretation of the large quantity of information on hand and to present it in formats that are suitable for the end users, the forest managers. The processes of organization and interpretation identify the areas that need more research, a critical part of research planning. The disciplinary research in entomology and other sciences is needed to fill the gaps and refine the key information. The process is iterative. If it stops at one round, then the gaps and problems tend to overwhelm the utility of the approach and to disenchant the end users. It is impossible to see how the iterative process can proceed without a solid core of scientific specialists working in collaboration with the generalists

Another consideration is that much thinking in the not too distant past has been based on a quite static view of the biosphere. Variability was accepted on a minor scale. It was acceptable that the earth had been different in ages past, but somehow there was a belief that the present was a fixed condition. This has all changed. Even if one does not accept the "greenhouse effect" projections, it is impossible not to recognize that we must be prepared to live in a dynamic environment that includes change outside the range of what has been the "normal" level of variability. It is also unchallengeable that part of the change is being caused by Man. More basic disciplinary research is needed to define the changes, to help prevent them when it is believed desirable, and to deal with their consequences when that is the only course available. This applies to entomology in relation to forests as much or more than to other ecosystems, because longer times are involved in forest succession and regeneration. In the article by Holden previously referred to, Thomas Eisner of Cornell University is quoted: 'Bugs are not going to inherit the earth. They own it now. So we might as well make peace with the landlord.' Making this peace requires a much better understanding of the insects' life systems especially where we are in direct competition for a resource as with forest pests, or where insects provide benefits in pest control, crop pollination, and food for other animals. To obtain this understanding requires more entomologists and more broadly-based research. The lag time between new fundamental discoveries and delivery of a useful product may be prolonged, and lapses in research activity may be very costly in the long term.

In keeping with the theme of the IUFRO World Congress to be held in Canada, and with the solid record of achievement in research in forest entomology in Canada, it needs to be said that as a nation in which the forest environment looms so large, we should capitalize on these assets and build upon the foundation that Canadian entomologists have established. Finally, to return to my title "Forest Entomology or Entomology in the Forest" ", I refer to Schwerdtfeger (1973) who quotes Ratzeburg, (1937, original not seen) as saying 'by forest insects we do not mean all insects living in the forest but only those which have influence on the thriving and the utility of those wood plants with which the forester is concerned.' This statement represents a viewpoint that is too narrow for the coming century of research, which must recognize the interrelationships of all the organisms in the forest ecosystem and their roles in maintaining the system.

\section{References}

Angus, T.A. 1964. Canadian participation in insect pathology. Can Ent. 96:231-241.

Anstey, T.H. 1986. One hundred harvests. Research Branch Agriculture Canada 1886-1986. Historical Series No. 27. Agric. Can., Ottawa.

Beirne, B.P. 1973. Influences on the development and evolution of biological control in Canada. Bull. Ent. Soc. Can. 5: 85-89.

Bird, F.T. and D.E. Elgee. 1957. A virus disease and introduced parasites as factors controlling the European spruce sawfly, Diprion hercyniae (Htg.), in central New Brunswick, Can. Ent. 89: 371-378.

Cody, W.J., Savile, D.B.O. and M.J . Sarazin, 1986. Systematics in Agriculture Canada at Ottawa. 1886-1986. Historical Series No. 28, 81p. Agric. Can., Ottawa

Corbet, P.S. and R.M. Prentice (Compilers). 1971. Biological control programmes against insects and weeds in Canada, 1959-1968. Tech. Commun. No. 4, Commonw. Inst. Biol. Control, Trinidad, 266p. Commonw. Agric. Bureaux, Slough, England.

Coulson, R.N., M.C. Saunders, D.K. Loh, F.L. Oliveria, D., Drummond, P.J. Barry, and K.M. Swain, 1989. Knowledge system environment for integrated pest management in forest landscapes: The southern pine bettle (Coleoptera:Scolytidae). Bull. Ent. Soc Amer. 35(2): 26-32.

de Gryse, J.J. 1947. Noxious forest insects and their control Reprinted from The Canada Yearbook 1947, 14p. Dom. Bur Stat., Dept. Trade Commerce, Ottawa 
Eidt, D.C. 1989. The future of spruce budworm research. Bull. Ent Soc. Can. 21: 45-48

Glen, R. 1956. Entomology in Canada up to 1956. Historical review. Can. Ent. 88: 292-300.

Graham, S.A. 1939. Principles of Forest Entomology. (2nd edition) 410p. McGraw-Hill Book Company, New York.

Henson, W.R. and R.W. Stark. 1988. William George Wellington: A tribute. In Memoirs Ent. Soc. Can. 146: 9-18.

Hewitt, C.G. 1910. Importance of entomology in the development of Canada. InRep. Select Standing Comm. on Agric. and Colon 1909-1910, 17-54, Otiawa.

Hewitt, C.G. 1912. The large larch sawfly (Nematus erichsonii) with an account of its parasites, other natural enemies and means of control. Bull. Dept. Agric. Can. (2nd Series), No. 10, 42p.

Holden, C. 1989. Entomologists wane as insects wax. Science 246 754-756

Hulme, M.A. 1988. The recent Canadian record in applied biological control of forest insects. For. Chron. 64(1): 27-31

Kelleher, J.S. and M.A. Hulme (Eds.). 1984. Biological Control Programmes Against Insects and Weeds in Canada 1969-1980. 410p. Commonw. Agric. Bur., Slough, England.

McGugan, B.M. 1958. The Canadian forest insect survey. Proc. 10th Int. Congr. Ent. 4: 219-232

McGugan, B.M. and H.C. Coppel. 1962. A review of the biological control attempts against insects and weeds in Canada. Part 2 - Biological control of forest insects, 1910-1958. Tech. Comm. No. 2, Commonw. Inst. Biol. Control, Trinidad, 35-216 Commonw. Agric. Bur., Farnham Royal, England

Prebble, M.L. 1956. Entomology in Canada up to 1956. Forest Entomology. Can. Ent. 88: 350-363.
Prebble, M.L. (Ed.) 1975. Aerial control of forest insects in Canada. 360p. Environ. Can., Ottawa

Reeks, W.A. 1953. The establishment of introduced parasites of the European spruce sawfly Diprion hercyniae $(\mathrm{Htg}$.) (Hymenoptera:Diprionidae) in the Maritime Provinces. Can. J. Agr. Sci. 33: $405-429$

Richmond, H.A. 1986. Forest entomology: From pack horse to helicopter. Pest Manag. Rep. No. 8, 44p. B.C. Min. For. and Lands, Victoria.

Schwerdtfeger, F. 1973. Forest entomology. InSmith, R.F., T.E. Mittler, and C.N. Smith (Eds.). History of Entomology. P. 381-386. Annual Reviews Inc., Palo Alta, CA.

Smith, S.M. and J.R. Carrow (Eds.) In press. Inundative release of the egg parasitoid, Trichogramma minutum (Hymenoptera: Trichogrammatidae), against forest insect pests such as the spruce budworm, Choristoneura fumiferana (Lepidoptera:Tortricidae), the Ontario Project 1982-1986. Memoirs Ent. Soc. Canada

Spencer, G.J. 1964. A century of entomology in Canada. Can. Ent 96: $33-59$

Swaine, J.M. 1928. Forest entomology and its development in Canada Pamphlet No. 97, 20p. Can. Dept. Agric., Ottawa

Swaine, J.M. 1933. The relation of insect activities to forest development as exemplified in the forests of eastern North America. Sci. Agr. 19(1): 8-31

Waters W.E. and R.W. Stark. 1980. Forest pest management: Concept and reality. Ann. Rev. Ent. 25: 479-509

Zeller, S. 1987. Inventing Canada: Early Victorian science and the Idea of a Transcontinental Nation. 356p. University of Toronto Press, Toronto, Buffalo, London.

\section{Malcolm L. Prebble. Forester, Scientist, Research Director - A Builder of Canada}

There are many milestones that mark the passage of a country like Canada from a pioneer community to a major nation recognized throughout the world. One of these markers is the ascendance of native born citizens to prominence in the fields of education and science. Malcolm L. Prebble, born in 1909 at Saint John, New Brunswick, for more than 40 years was a principal contributor to the development of forest entomology in Canada and internationally.

Malcolm Prebble was first of all a forester. In 1930 he was awarded the Governor General's Medal upon graduation from the University of New Brunswick with a B.Sc. degree in Forestry, and then went on to obtain MSc. (1932) and Ph.D. (1940) degrees in entomology from McGill University. His employment career in forestry started in 1927 when he undertook field surveys in northern New Brunswick. In the summer of 1928 he worked at the Dominion Entomology Laboratory in Fredericton, beginning an association that continued until 1940

The European spruce sawfly was discovered in an outbreak on the Gaspé Peninsula of Quebec in 1930 and became a serious threat to the spruce forests of eastern North America. Malcolm Prebble spent the decade of the '30s investigating the ecophysiology of this pest. This principal scientific phase of Dr. Prebble's career is an outstanding example of the development of the modern team approach to the study of a pest problem. His work on quantitative field sampling techniques was in the best tradition of our current science and it was carried out without the aid of modern electronic data gathering and analytical tools. His studies of the diapause were based on both field ecology and laboratory experimentation, in clear contrast with the more

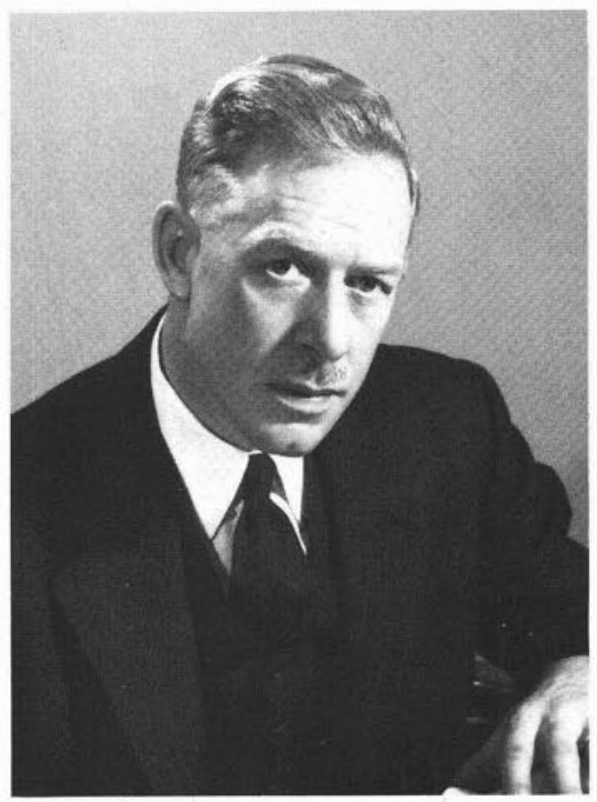

Malcolm L. Prebble, 1947. Officer in charge, Forest Insect Laboratory, Sault Ste. Marie, Ontario

museum/cataloging approaches evident in much of earlier entomology. The ultimate result of the work of this team in which Dr. Prebble played a major role was the rescue of the spruce forests of eastern North America from destruction.

In 1940 Malcolm Prebble was transferred to Victoria, British Columbia to develop a research establishment with responsibility for research on forest and shade tree pests in the coastal regions. Subsequently, this laboratory became the centre of federal forest entomology in the province. 
In 1945, he was once again given a major new responsibility in the growing Division of Forest Insect Investigations. This time his assignment was to take over leadership of the Forest Insect Laboratory in Sault Ste. Marie, Ontario. The laboratory had just been built by the Ontario Department of Lands and Forests under a federal provincial agreement that gave the federal government responsibility for equipping, staffing, and operating the facility. Dr. Prebble brought together a group of enthusiastic scientists and guided them in the development of a strong research program.

Malcolm Prebble succeeded Mr. J.J. DeGryse as Director of the Forest Biology Division of Agriculture Canada in Ottawa in 1952. From then until retirement in 1974, he served as a senior science manager and, for several years as an Assistant Deputy Minister. Forest entomological and pathological investigations were brought together with other aspects of forestry during this period and Dr. Prebble's advice and guidance played an important part in this integration. $\mathrm{He}$ ended his career as a Special Advisor to the Minister of the Environment in which capacity he arranged and edited a compendium on aerial forest spraying in Canada since 1927.

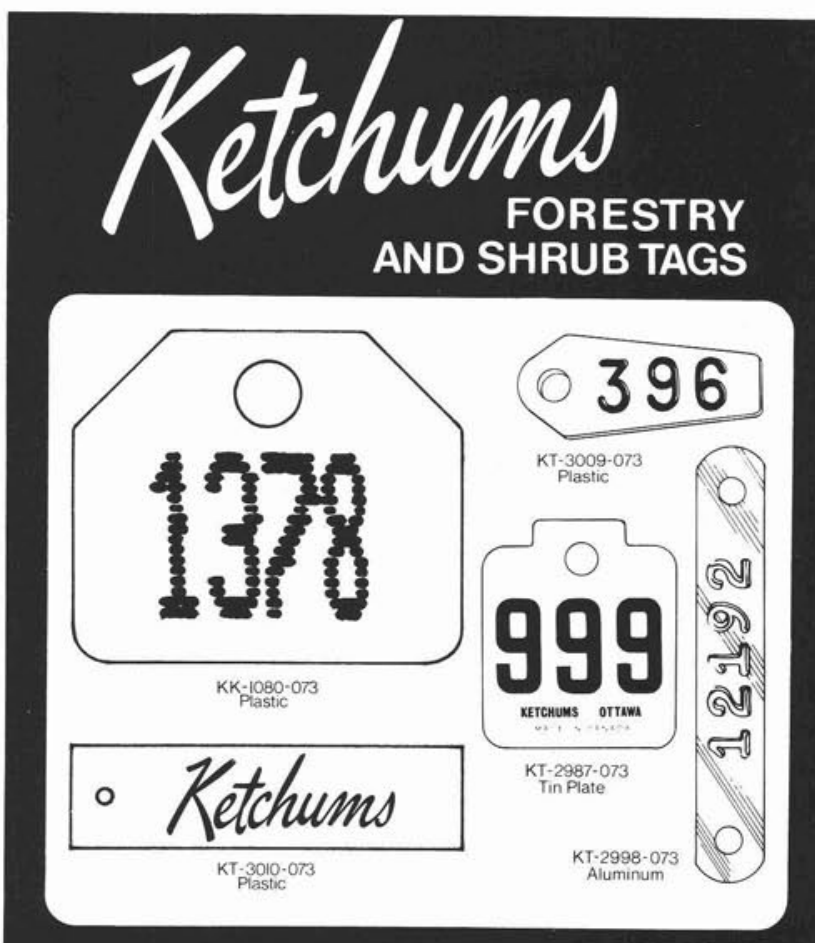

Samples available upon request

KETCHUM MANUFACTURING SALES LIMITED

396 Berkley Avenue

Ottawa, Ontario, Canada K2A 2G6

(613) $722-3451$
Dr. Prebble was active in national and international scientific, professional and governmental associations. His great contributions to entomology and research in Canada were recognized in 1985 when he was awarded the Gold Medal of the Entomological Society of Canada.

Malcolm Prebble was noted for the determination and energy with which he undertook any task, official or recreational, from lighting his pipe to his reputed construction of disaster-proof outbuildings. He believed in working alongside his people no matter what the job and spent as much time as possible visiting field locations and labs. Dr. Prebble, covertly and respectfully called "Pinky" in reference to his complexion and hair, had a way of listening to and looking at us that stripped secrets bare, yet he chose to overlook many of our not-so-prudent activities. One of the greatest tributes to Malcolm Prebble can be realized by looking at the many aspects of entomology that he influenced directly and the number of colleagues that he helped and advised who have also been innovators in entomology.

D.R. Wallace

\section{HARDWOOD RESEARCH COUNCIL announces its \\ SEVENTH ANNUAL COMPETITION for \\ OUTSTANDING ORIGINAL RESEARCH}

The Hardwood Research Council is now receiving entries for its Seventh Annual Competition for Outstanding Original Research in the area of hardwood forest management research. The winner receives a $\$ 1000$ cash award plus an all expenses paid trip to the Council's 1991 Annual Hardwood Symposium to present the winning paper.

Entry applications are available by writing to the Hardwood Research Council, P.O. Box 34518, Memphis, TN 38184-0518.

All entries must be received not later than October 5, 1990. 